\title{
Optimasi Carbomer, Propilen Glikol, dan Trietanolamin Dalam Formulasi Sediaan Gel Ekstrak Etanol Daun Kembang Bulan (Tithonia diversifolia)
}

\author{
Optimization of Carbomer, Propilen Glycol, and Triethanolamine on \\ Formulation of Gel with Kembang Bulan Leaves (Tithonia diversifolia) Ethanol \\ Extract
}

\author{
Amira Fawwaz Tsabitah1, Abdul Karim Zulkarnain"1*, Mae Sri Hartanti Wahyuningsih², Dwi \\ Aris Agung Nugrahaningsih ${ }^{2}$ \\ ${ }^{1}$ Fakultas Farmasi, Universitas Gadjah Mada \\ ${ }^{2}$ Fakultas Kedokteran Kesehatan Masyarakat dan Keperawatan, Universitas Gadjah Mada \\ Corresponding author: Abdul Karim Zulkarnain: Email: akarimzk08@gmail.com \\ Submitted: 14-05-2019 Revised: 12-06-2019 Accepted: 12-06-2019
}

\begin{abstract}
ABSTRAK
Ekstrak etanol daun kembang bulan atau Tithonia diversifolia telah diteliti memiliki kemampuan sebagai anti keloid yang baik. Tujuan penelitian ini adalah untuk mendapatkan formula gel dengan sifat fisik dan stabilitas yang baik. Metode yang digunakan dalam optimasi ini adalah Simplex Lattice Design. Formula optimum gel dibuat dari bahan carbomer, propilen glikol, dan trietanolamin. Parameter yang diukur adalah viskositas, $\mathrm{pH}$, daya sebar, freeze and thaw cycles, dan sineresis. Hasil uji kemudian dianalisis menggunakan paired t-test. Hasil penelitian menunjukan bahwa formula optimum gel terdiri dari 0,81\% carbomer, 5,9\% propilen glikol, dan 0,58\% trietanolamin dengan viskositas 155,96 d.Pas, daya sebar 4,06 cm, pH 5,50, dan sineresis 0,64\%. Basis gel yang dihasilkan bening, memiliki viskositas 156,10 $\pm 2,87$ d.Pas, daya sebar 3,95 $\pm 0,07 \mathrm{~cm}$, pH 5,50 \pm 0,00, dan sineresis 0,46 0,00\%. Sediaan basis gel stabil dalam uji stabilitas fisik. Gel ekstrak etanol daun kembang bulan yang dihasilkan memiliki viskositas 77,70 \pm 2,30 d.Pas, daya

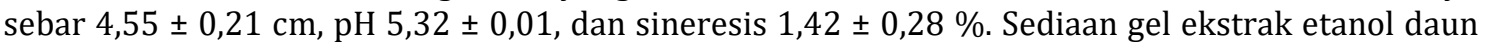
kembang bulan kurang stabil dalam uji stabilitas fisik pada viskositas yang mengalami penurunan, daya sebar yang mengalami kenaikan, pH yang mengalami kenaikan, dan sineresis yang meningkat. Kata kunci: gel; ekstrak; kembang bulan; SLD
\end{abstract}

\begin{abstract}
Ethanol extract of kembang bulan leaves or Tithonia diversifolia has been investigated of having anti keloid ability. Purpose of this study is to obtain a formula with good physical and stability properties. The method used in this optimization is Simplex Lattice Design. The optimum formula of the gel is made from carbomer, propylene glycol, and triethanolamine. The parameters measured were viscosity, $\mathrm{pH}$, dispersion, freeze and thaw cycles, and syneresis. The test results were then analyzed using a paired t-test. The results showed that the optimum gel formula consisting of $0.81 \%$ carbomer, $5.9 \%$ propylene glycol, and $0.58 \%$ triethanolamine with a viscosity of 155.96 d.Pas, a spread of $4.06 \mathrm{~cm}, \mathrm{pH} 5.50$, and sineresis $0.64 \%$. The gel base produced was clear, had a viscosity of $156.10 \pm 2.87$ d.Pas, spreadability was $3.95 \pm 0.07 \mathrm{~cm}$, pH was $5.50 \pm 0.00$, and syneresis was $0.46 \pm$ $0.00 \%$. The gel base preparation is stable in the physical stability test. The yield of ethanol extract gel from the kembang bulan leaves has a viscosity of $77.70 \pm 2.30 \mathrm{~d}$.Pas, a spread of $4.55 \pm 0.21 \mathrm{~cm}, \mathrm{pH}$ of $5.32 \pm 0.01$, and syneresis $1.42 \pm 0.28 \%$. The preparation of ethanol extract of the leaves of kembang bulan gel was less stable in the test of physical stability on decreased viscosity, increased spreadability, increased $\mathrm{pH}$, and increased syneresis.
\end{abstract}

Keywords: gel; extract; kembang bulan; SLD 


\section{PENDAHULUAN}

Keloid adalah salah satu inflamasi dengan waktu yang panjang dan bersifat lokal yang kerap dialami oleh manusia dewasa ini. Keloid disebabkan oleh luka pada kulit dan iritasi (Ogawa, 2017). Keloid diakibatkan oleh proses penyembuhan luka dan terjadinya sintesis serta penumpukan kolagen yang tidak terkontrol pada kulit. Prevalensi terjadinya keloid pada negara berkembang setiap tahunnya sebanyak 100 juta pasien dimana diantaranya sebanyak 55 juta pasien menderita keloid karena pembedahan elektif dan 25 juta diantaranya karena pembedahan trauma (Andisi dkk., 2016). Penelitian menunjukan bahwa ekstrak etanol daun kembang bulan memiliki aktivitas antifibrotik yang dapat berperan dalam penyembuhan keloid (Wahyuningsih dkk., 2015). Daun kembang bulan diteliti mengandung senyawa flavonoid dan seskuiterpen (Sasmita dkk., 2017). Seskuiterpen lakton pada daun kembang bulan yaitu Tagitinin $\mathrm{C}$ diketahui memiliki aktivitas antitumor dan diduga dapat menghambat dan menghentikan pertumbuhan keloid (Ziemons dkk., 2005). Penelitian yang dilakukan oleh Wahyuningsih dkk. (2015) menyatakan bahwa ekstrak etanol daun kembang bulan menunjukan adanya aktivitas antifibrotik dalam penyembuhan fibroblast keloid.

Sediaan topikal adalah rute pemberian obat yang paling menarik untuk dipilih. Sediaan topikal cocok untuk terapi penyakit kulit yang bersifat local karena dapat memberikan absorbs yang baik dengan berpenetrasi langsung melalui kulit, selain itu sediaan topical dianggap paling efektif dan paling tidak toksik (Kaur \& Guleri, 2013). Sediaan gel banyak diminati industri obat dan kosmetik karena memiliki keunggulan dibandingkan sediaan yang lain yaitu penyebaran yang baik di kulit, adanya efek dingin ketika diaplikasikan di kulit, pelepasan obat yang baik, serta mudah dicuci.

Sediaan farmasi memiliki mutu yang baik jika tidak toksik, efektif, efisien, stabil, dan nyaman. Untuk memenuhi kriteria tersebut, perlu dilakukan adanya optimasi dalam melakukan formulasi sediaan sehingga sediaan dapat mencapai tempat terapi yang diinginkan, memiliki ketoksikan seminimal mungkin, kestabilan tinggi dan sebisa mungkin tidak mengganggu aktivitas sehari-hari. Optimasi dilakukan menggunakan bahan carbomer sebagai gelling agent, propilen glikol sebagai humektan, dan triethanolamine sebagai alkalizing agent. Carbomer dipilih karena mudah didispersikan dalam air hanya dengan konsentrasi yang kecil dan propilen glikol berfungsi untuk memperbaiki sifat carbomer jika mengikat obat terlalu kuat dengan menambah kelarutan bahan obat, ketika kelarutan obat bertambah maka obat akan lebih mudah untuk dilepaskan dari basisnya dan akan meningkatkan efektivitas obat tersebut (Melani dkk., 2005). Triethanolamin dipilih karena dapat memberikan suasana basa pada carbomer sehingga membuat gel yang dihasilkan menjadi kental dan jernih (Septiawan,2012).

Gelling agent, humektan ,dan alkalizing agent adalah komponen penting yang sangat berpengaruh pada sifat fisik dan stabilitas sediaan gel. Sifat fisik yang dimaksud antara lain viskositas, daya sebar, $\mathrm{pH}$, dan organoleptis, sedangkan stabilitas yang dimaksud adalah perubahan viskositas gel, perubahan $\mathrm{pH}$, dan sineresis. Pembuatan gel kali ini gelling agent yang digunakan adalah carbomer, humektan yang digunakan adalah propilen glikol, dan alkalizing agent yang digunakan adalah triethanolamin. Optimasi dari gelling agent, humektan, dan alkalizing agent yang digunakan diperlukan untuk menemukan sifat fisik dan stabilitas sediaan gel yang paling optimum. Aplikasi simplex lattice design digunakan untuk menentukan area komposisi gelling agent dan humektan yang paling optimum dalam pembuatan sediaan gel ekstrak etanolik daun kembang bulan ini.

Carbomer akan membentuk ikatan hidrogen dengan air ketika dicampurkan dan akan terdispersi dalam air, untuk mencegah terlarutnya seluruh carbomer dalam air maka diperlukan agen untuk menetralisasi carbomer untuk membentuk massa gel. Agen penetral tersebut salah satunya adalah TEA (Trietanolamin), TEA akan mengionisasi carbomer, menghasilkan muatan negatif sepanjang struktur blackbone polimer sehingga menghasilkan adanya tolakan elektrostatik. Akibat adanya tolakan elektristatik tersebut terbentuklah struktur tiga dimensi diperpanjang yang membentuk adanya massa gel yang padat. Banyaknya carbomer yang digunakan menentukan viskositas sediaan gel yang akan dibuat, semakin banyak carbomer yang ditambahkan maka viskositas akan semakin meningkat, sedangkan penurunan jumlah carbomer akan menurunkan viskositas. 
Tabel I. Variasi komponen gelling agent

\begin{tabular}{|c|c|c|c|c|c|c|c|}
\hline \multirow{2}{*}{$\begin{array}{c}\text { Bahan } \\
(\% \text { b/b) }\end{array}$} & \multicolumn{7}{|c|}{ Run } \\
\hline & 1 & 2 & 3 & 4 & 5 & 6 & 7 \\
\hline *Carbomer & 0,67 & 0,60 & 0,73 & 0,60 & 0,60 & 1 & 0,80 \\
\hline *Propilen Glikol & 8,34 & 5 & 6,60 & 10 & 5 & 5 & 5 \\
\hline *Trietanolamin & 0,5 & 1 & 0,6 & 0,4 & 1 & 0,40 & 0,70 \\
\hline Metil Paraben & 0,2 & 0,2 & 0,2 & 0,2 & 0,2 & 0,2 & 0,2 \\
\hline Propil Paraben & 0,1 & 0,1 & 0,1 & 0,1 & 0,1 & 0,1 & 0,1 \\
\hline aqua rosae & q.s & q.s & q.s & q.s & q.s & q.s & q.s \\
\hline Akuades ad & 100 & 100 & 100 & 100 & 100 & 100 & 100 \\
\hline Bahan & \multicolumn{7}{|c|}{ Run } \\
\hline$(\% \mathrm{~b} / \mathrm{b})$ & 8 & 9 & 10 & 11 & 12 & \multicolumn{2}{|c|}{13} \\
\hline *Carbomer & 1 & 0,60 & 0,67 & 0,80 & 0,87 & \multicolumn{2}{|c|}{0,60} \\
\hline *Propilen Glikol & 5 & 10 & 5,84 & 7,5 & 5,84 & \multicolumn{2}{|c|}{7,5} \\
\hline *Trietanolamin & 0,40 & 0,40 & 0,80 & 0,40 & 0,50 & \multicolumn{2}{|c|}{0,7} \\
\hline Metil Paraben & 0,2 & 0,2 & 0,2 & 0,2 & 0,2 & \multicolumn{2}{|c|}{0,2} \\
\hline Propil Paraben & 0,1 & 0,1 & 0,1 & 0,1 & 0,1 & \multicolumn{2}{|c|}{0,1} \\
\hline aqua rosae & q.S & q.s & q.s & q.s & q.s & \multicolumn{2}{|c|}{ q.s } \\
\hline Akuades ad & 100 & 100 & 100 & 100 & 100 & \multicolumn{2}{|c|}{100} \\
\hline
\end{tabular}

Dengan demikian jumlah carbomer yang ditambahkan menentukan respon viskositas dan daya sebar karena viskositas berkolerasi dengan daya sebar. Viskositas sediaan gel dengan gelling agent carbomer akan netral pada pH sekitar 6-11 (Rowe dkk., 2009).

Carbomer sendiri sering dipilih karena memiliki beberapa keuntungan yaitu bersifat hidrofil sehingga lebih mudah terdispersi dalam air meski konsentrasi yang digunakan kecil, dengan konsentrasi kecil tersebut carbomer sudah memiliki viskositas yang cukup sebagai basis gel (Rowe, dkk.,2009). Menurut Rowe dkk (2009) konsentrasi carbomer yang baik untuk pembuatan gel adalah pada rentang 0,5\%-2\%. Carbomer berwarna putih, tersturnya seperti bulu, memiliki bau yang khas, memiliki keasaman yang tinggi, dan higroskopis. Formulasi untuk sediaan topikal perlu dilakukan adanya penaikan $\mathrm{pH}$ agar menjadi $\mathrm{pH}$ netral atau sesuai dengan $\mathrm{pH}$ kulit karena carbomer sifatnya terlalu asam (Rowe dkk., 2009).

Humektan juga berperan menjaga kehilangan air dari dalam gel sehingga gel akan lebih stabil. Humektan yang akan digunakan adalah propilen glikol. Propilen glikol adalah cairan jernih, teksturnya kenyal, tidak berwarna, tidak berbau, rasanya maris mirip gliserin. Selain sebagai humektan, propilen glikol juga bisa digunakan sebagai pelarut, ekstraktan, pengawet, disinfektan, dana gen antimikroba. Propilen glikol stabil pada suhu rendah dan wadah tertutup karena terhindar dari agen pengoksidasi. Kestabilan propilen glikol bisa ditambah dengan menambahkan etanol 95\% dan gliserin atau air (Rowe dkk., 2009). Penelitian yang dilakukan oleh Qisti dkk (2018) yaitu optimasi menggunakan formula yang mengandung propilen glikol dengan rentang kadar propilen glikol 5\%-30\%. Penggunaan propilen glikol yang digunakan pada penelitian Patil dkk. (2015) adalah 1\%-4\% untuk mendapatkan gel yang baik.

Agen pengalkali yang akan digunakan adalah trietanolamin. Trietanolamin berfungsi menetralkan keasaman carbomer sehingga sediaan gel yang dibuat akan jernih (Rowe,2009). Triethanolamin adalah cairan kental, berwarna bening hingga kuning pucat, memiliki bau lebah mirip amoniak, dan bersifat higroskopis. Kelarutan triethanolamine adalah mudah larut dalam air, ethanol 95\% P, dan dalam kloroform. Penelitian yang dilakukan oleh Rahman dkk. (2013) menggunakan triethanolamine dengan konsentrasi 0,4\%-0,5\% untuk menghasilkan sediaan yang baik. Penelitian yang dilakukan Aeni dkk. (2012) menggunakan triethanolamine dengan konsentrasi 0,56\% untuk menghasilkan gel yang baik.Optimasi formula gel dapat dilakukan dengan SLD yang dapat memprediksikan respon yang terjadi berdasarkan data yang diperoleh dari hasil eksperimen (Bolton dan Bon, 2010). 
Optimasi formula gel dilakukan dengan cara mengoptimasi gelling agent carbomer dengan kadar 0,6\%-0,1\%; propilen glikol dengan kadar 5,0\%-10,0\%; dan trietanolamin dengan kadar 0,4\%-1,0\%. Respon yang digunakan untuk melakukan optimasi pada studi ini adalah $\mathrm{pH}$, viskositas, daya sebar, dan sineresis. Keempat respon tersebut digunakan untuk menentukan formula optimum sediaan gel dengan metode Simplex Lattice Design (SLD) menggunakan perangkat lunak Design Expert $\AA$ versi 10.0.1.

\section{METODE}

\section{Bahan dan Alat}

Bahan-bahan yang digunakan adalah ekstrak etanol daun kembang bulan (Lab. Farmakologi, FKKMK UGM), aquadest, carbomer (farmasetis), propilen glikol (farmasetis), metil paraben (farmasetis), propil paraben (farmasetis), trietanolamin (farmasetis).

Alat penelitian yang digunakan dalam penelitian ini adalah alat-alat gelas (Pyrex $囚$ ), neraca analitik (Mettler Toledo®), refrigerator, kompor listrik (Robusca), pot plastik, stirrer (Stuartß), alat uji daya sebar, alat uji daya lekat, viskosimeter Brookfied (DV-I Prime), oven (Memmert), pH-Meter (HANNA H1 5211), alat uji daya sebar (Laboraturium Teknologi Farmasi, Fakultas Farmasi UGM).

\section{Pembuatan basis gel}

Carbomer dikembangkan dalam 20 gram aquadest yang telah ditambah triethanolamine 0,2 gram dengan cara menaburkan carbomer diatas aquadest untuk menetralkan carbomer yang dikembangkan. Pengembangan dilakukan selama 24 jam. Metil paraben dan propil paraben dilarutkan dengan propilen glikol. Campuran metil paraben dan propilen glikol serta carbomer dicampur dengan ekstrak etanol daun kembang bulan dan ditambah aquades hingga volume yang dikehendaki, kemudian proses mixing menggunakan stirrer selama 20 menit dengan kecepatan rendah. Setelah itu ditambahkan trietanolamin untuk mengatur $\mathrm{pH}$ sediaan gel ekstrak etanol daun kembang bulan secara perlahan tetes demi tetes (Sari \& Isadiartuti, 2006).

\section{Pengujian sifat fisik gel}

Pengujian sifat fisik 13 run formula yang dilakukan untuk memperoleh formula optimum meliputi pengamatan organoleptis, pengukuran $\mathrm{pH}$, viskositas, daya sebar, dan sineresis.

\section{Penentuan formula optimum basis gel}

Penentuan formula optimum dilakukan dengan cara mengolah data sifat fisik 13 run formula dengan perangkat lunak Design Expert ${ }^{\circledR}$ versi 10.0. Respon sifat fisik yang diamati yaitu $\mathrm{pH}$, viskositas, daya sebar, dan sineresis. Target respon dan derajat kepentingan disesuaikan untuk memperoleh kombinasi gelling agent yang optimal. Sifat fisik basis gel formula optimum dibandingkan dengan sifat fisik gel ekstrak etanol daun kembang bulan. Gel ekstrak etanol daun kembang bulan adalah basis gel formula optimum yang didalamnya terkandung $1 \%$ ekstrak etanol daun kembang bulan. Data sifat fisik dari kedua gel dibandingkan dengan uji $\mathrm{t}$ berpasangan untuk mengetahui apakah penambahan ekstrak etanol daun kembang bulan berpengaruh terhadap sifat fisik basis gel formula optimum atau tidak.

\section{Verifikasi formula optimum basis gel}

Dibuat formula optimum yang disarankan oleh software Design Expert $\AA$ versi 10.0 dengan metode yang sama seperti pembuatan 13 run formula sebelumnya. Basis gel formula optimum diuji sifat fisiknya dan dibandingkan dengan sifat fisik hasil prediksi dari software Design Expert $\AA$ versi 10.0. Sifat fisik yang diamati meliputi $\mathrm{pH}$, viskositas, daya sebar, dan sineresis. Uji t satu sampel dengan taraf kepercayaan 95\% dilakukan terhadap data sifat fisik basis gel formula optimum untuk mengetahui apakah sifat fisik basis gel hasil percobaan berbeda signifikan dengan prediksi yang dihasilkan software Design Expert $®$ versi 10.0 atau tidak.

Evaluasi sifat fisik basis gel formula optimum dan gel ekstrak etanol daun kembang bulan

Uji sifat fisik basis gel formula optimum dan gel ekstrak etanol daun kembang bulan meliputi pengamatan organoleptis, pengukuran $\mathrm{pH}$, viskositas, daya sebar, dan uji sineresis gel.

\section{Pengukuran pH}

Pengukuran $\mathrm{pH}$ dilakukan menggunakan alat pH-Meter Hanna H1 5211. Uji pH dilakukan terhadap masing-masing formula gel dengan menggunakan $\mathrm{pH}$ meter semi padat yang telah 
Optimasi Carbomer, Propilen Glikol, dan Trietanolamin Dalam Formulasi Sediaan Gel

Tabel II. Hasil uji sifat fisik 13 formula gel

\begin{tabular}{ccccc}
\hline Run & Viskositas (d.PaS) & Daya Sebar $(\mathbf{c m})$ & pH & Sineresis (\%) \\
\hline $\mathbf{1}$ & 125,8 & 4,225 & 5,46 & 2,7 \\
$\mathbf{2}$ & 122,5 & 4,500 & 7,49 & 1,6 \\
$\mathbf{3}$ & 146 & 3,950 & 5,76 & 1,35 \\
$\mathbf{4}$ & 115,8 & 4,450 & 5,66 & 0,7 \\
$\mathbf{5}$ & 123,7 & 4,550 & 7,21 & 1,45 \\
$\mathbf{6}$ & 184 & 3,175 & 4,9 & 1,85 \\
$\mathbf{7}$ & 157,7 & 3,675 & 5,85 & 1,5 \\
$\mathbf{8}$ & 193,4 & 3,125 & 4,47 & 1,8 \\
$\mathbf{9}$ & 109,6 & 4,625 & 5,44 & 1,25 \\
$\mathbf{1 0}$ & 144,8 & 4,050 & 6,09 & 1,1 \\
$\mathbf{1 1}$ & 153,9 & 3,850 & 4,94 & 1,05 \\
$\mathbf{1 2}$ & 143,3 & 4,025 & 5,04 & 0,99 \\
\hline
\end{tabular}

dikalibrasi dengan larutan dapar $\mathrm{pH} 4, \mathrm{pH} 7$, dan pH 10 (Guci, 2015). Nilai pH pada sediaan gel harus berkisar pada $\mathrm{pH}$ yang netral atau sesuai untuk kulit yaitu 4,5-6,5 (Zulkarnain dkk., 2015).

\section{Uji viskositas}

Uji viskositas dilakukan dengan menggunakan alat viskosimeter Brookfield DV-I Prime dengan spindle nomor tujuh. Gel diambil sejumlah 80 gram dan dituangkan ke dalam wadah untuk diamati viskositasnya dengan menggunakan alat viskosimeter Brookfield. Spindle yang digunakan disesuaikan dengan viskositas gel nantinya berdasarkan hasil nilai torque yang didapat pada viskosimeter. Gel dimasukan ke dalam wadah selanjutnya spindle dimasukan dalam wadah sehingga terendam untuk mengetahui viskositas gel. Viskosimeter dijalankan sehingga viskosimeter Brookfield dapat menunjukan besarnya viskositas (Zulkarnain dkk., 2015).

\section{Uji daya sebar}

Pengukuran uji daya sebar dilakukan dengan menimbang 0,5 gram gel kemudian diletakan ditengah lempeng bulat berskala. Di atas gel diletakan kaca bulat lain dan pemberat dengan beban yang bervariasi, lalu ditunggu 1 menit setiap pernambahan beban dan diukur diameter sebarnya (Zulkarnain dkk., 2015).

Penambahan beban dilakukan setiap 1 menit dengan beban 50 gram hingga berat total beban yang ditambahkan 150 gram (Sayuti, 2015).

\section{Uji sineresis gel}

Uji sineresis dilakukan dengan menyimpan gel pada suhu $\pm 10^{\circ} \mathrm{C}$ selama 72 jam. Masing masing gel ditempatkan pada cawan untuk menampung air yang dibebaskan dari gel selama penyimpanan. Sineresis dihitung dengan mengukur kehilangan berat selama penyimpanan lalu dibandingkan dengan berat awal gel (Kuncari dkk., 2014).

\section{Uji stabilitas fisik gel}

Uji stabilitas fisik gel dilakukan dengan metode freeze thaw cycling. Uji stabilitas dipercepat dengan metode freeze thaw cycling dilakukan dengan menyimpan sediaan selama tiga siklus. Satu siklus penyimpanan terdiri dari 24 jam penyimpanan pada suhu $8^{\circ} \mathrm{C}$ dan 24 jam penyimpanan pada suhu $45^{\circ} \mathrm{C}$. Digunakan parameter pergeseran sifat fisik gel yaitu peregeseran viskositas, daya sebar, $\mathrm{pH}$, dan sineresis gel (Zulkarnain dkk., 2015).

\section{HASIL DAN PEMBAHASAN}

Sifat Fisik 13 Run Formula, Basis Gel Formula Optimum, dan Gel Ekstrak Etanol Daun Kembang Bulan

Hasil pengamatan organoleptis 13 run formula menunjukkan karakteristik yang identik, yaitu gel yang sedikit bergelembung, bening, berbau khas aqua rosae, dan homogen.

Hasil pengukuran $\mathrm{pH}$ dari 13 run formula menunjukkan bahwa seluruh run formula memenuhi syarat $\mathrm{pH}$ yang baik untuk kulit yaitu 4,5-6, Run 8 menghasilkan pH yang paling 

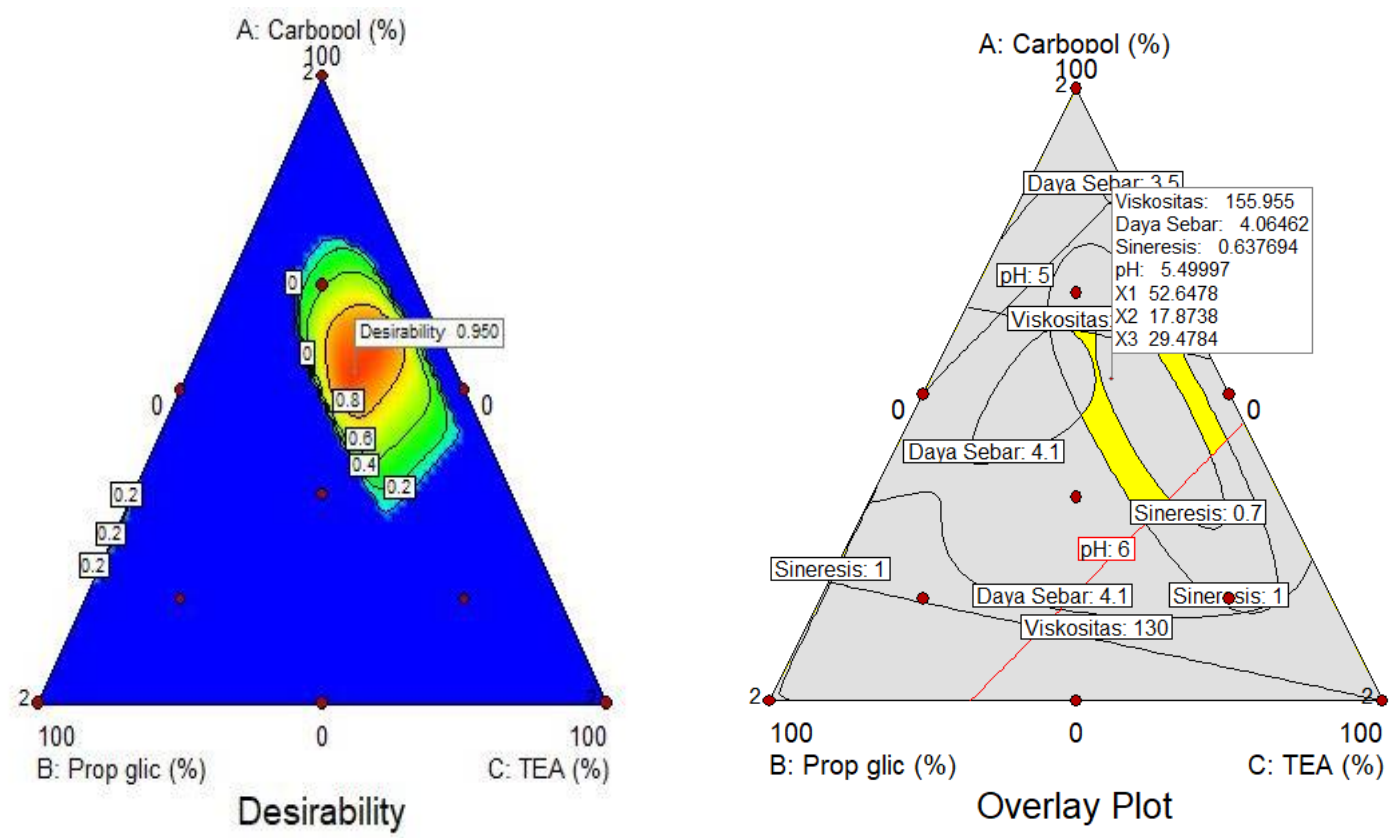

Gambar 1. Grafik desirability dan superimposed contour plot formula optimum gel.

rendah, sedangkan run 2 menghasilkan pH yang paling tinggi.

Hasil pengukuran viskositas yang dilakukan pada 13 run formula menunjukkan formula pada run 6 menghasilkan viskositas yang paling tinggi, sedangkan run 9 menghasilkan viskositas yang paling rendah.

Hasil pengukuran daya sebar menunjukkan bahwa run 13 menghasilkan daya sebar paling tinggi, sedangkan run 8 menghasilkan daya sebar paling rendah. Sediaan topikal yang mudah menyebar pada permukaan kulit lebih disukai karena pemakaiannya lebih mudah dan nyaman.

Hasil pengukuran sineresis menunjukan bahwa run 4 memiliki nilai sineresis yang paling rendah dan run 1 memiliki nilai sineresis yang paling tinggi. Semakin kecil nilai sineresis mka sediaan gel semakin stabil.

\section{Penentuan formula optimum basis gel}

Parameter yang digunakan untuk menentukan formula optimum pada penelitian ini adalah $\mathrm{pH}$, viskositas, daya sebar, dan dineresis. Software Design Expert $\AA$ versi 10.0 memberikan satu solusi formula yang sesuai dengan target optimasi yang diinginkan. Solusi yang dipilih memiliki nilai desirability tertinggi yaitu solusi dengan nilai desirability 0,950. Formula optimum yang dipilih adalah formula dengan komposisi karbopol sebesar 0,81\%; propilen glikol sebesar 5,9\%; dan trietanolamin sebesar 0,58\%. Formula optimum diprediksikan memiliki pH sebesar 5,5; viskositas sebesar 155,96 dPa.s; daya sebar sebesar 4,0647 cm; dan sineresis sebesar $0,64 \%$.

\section{Verifikasi Basis Gel Formula Optimum}

Formula optimum diverifikasi dengan cara membandingkan sifat fisik sediaan gel yang dibuat dengan sifat fisik gel yang diprediksikan menggunakan uji t satu sampel dengan taraf kepercayaan 95\%. Data sifat fisik diolah menggunakan software SPSS Statistic. Hasil uji t satu sampel menyatakan bahwa nilai $\mathrm{pH}$, viskositas, daya sebar, dan sineresis gel hasil percobaan tidak berbeda signifikan dari nilai yang diprediksikan.

\section{Komparasi Respon Sifat Fisik Basis Gel Formula Optimum dan Gel Ekstrak Etanol Daun Kembang Bulan}

Respon sifat fisik basis gel formula optimum dan gel ekstrak etanol daun kembang bulan dibandingkan dengan uji t berpasangan. Sifat fisik yang dibandingkan yaitu $\mathrm{pH}$, viskositas, daya sebar, dan sineresis. Hasil uji t berpasangan menunjukkan adanya perbedaan signifikan antara viskositas, daya sebar, $\mathrm{pH}$, dan sineresis dari kedua gel. Hal ini dapat 
Optimasi Carbomer, Propilen Glikol, dan Trietanolamin Dalam Formulasi Sediaan Gel

Tabel II. Komparasi respon sifat fisik basis gel formula optimum dan gel ekstrak etanol daun kembang bulan

\begin{tabular}{ccccc}
\hline Formula & pH & Viskositas (dPa.s) & Daya sebar (cm) & Sineresis (\%) \\
\hline $\begin{array}{c}\text { Basis gel } \\
\text { Gel ekstrak }\end{array}$ & $5,50 \pm 0,00$ & $156,10 \pm 2,87$ & $3,95 \pm 0,07$ & $0,46 \pm 0,00$ \\
kembang bulan & $5,32 \pm 0,01$ & $77,70 \pm 2,30$ & $4,55 \pm 0,21$ & $1,42 \pm 0,28$ \\
\hline
\end{tabular}

Tabel IV. Perbandingan sifat fisik setelah uji stabilitas dan nilai signifikansi sifat fisik gel ekstrak etanol daun kembang bulan

\begin{tabular}{cccc}
\hline Respon & Sebelum cycling test & Sesudah cycling test & Sig \\
\hline & $\begin{array}{c}\text { Warna hijau tua, bau khas } \\
\text { aqua rosae, bentuk gel } \\
\text { encer, tidak terdapat } \\
\text { Oumpalan partikel dan } \\
\text { mudah dioleskan }\end{array}$ & $\begin{array}{c}\text { Warna hijau tua, bau khas aqua } \\
\text { rosae, bentuk gel encer, tidak } \\
\text { terdapat gumpalah, dan mudah } \\
\text { dioleskan }\end{array}$ & - \\
Viskositas (d.PaS) & $77,70 \pm 2,30$ & $35,80 \pm 1,53$ & 0,000 \\
pH & $5,32 \pm 0,01$ & $5,80 \pm 0,02$ & 0,027 \\
Daya sebar (cm) & $4,55 \pm 0,21$ & $5,50 \pm 0,39$ & 0,000 \\
Sineresis (\%) & $1,42 \pm 0,28$ & $1,87 \pm 0,14$ & 0,011 \\
\hline
\end{tabular}

Tabel V. Perbandingan sifat fisik setelah uji stabilitas dan nilai signifikansi sifat fisik basis gel

\begin{tabular}{cccc}
\hline Respon & Sebelum cycling test & Sesudah cycling test & Sig \\
\hline Organoleptis & $\begin{array}{c}\text { Warna bening, bau khas } \\
\text { aqua rosae, bentuk gel } \\
\text { kental, tidak terdapat } \\
\text { gumpalan partikel dan } \\
\text { mudah dioleskan }\end{array}$ & $\begin{array}{c}\text { Warna bening, bau khas aqua } \\
\text { rosae, bentuk gel kental, tidak } \\
\text { terdapat gumpalan, dan mudah }\end{array}$ & - \\
& $156,10 \pm 2,87$ & dioleskan & \\
Viskositas (d.PaS) & $5,50 \pm 0,00$ & $154,10 \pm 0,48$ & 0,217 \\
pH & $3,95 \pm 0,07$ & $5,52 \pm 0,01$ & 0,102 \\
Daya sebar (cm) & $0,46 \pm 0,00$ & $4,46 \pm 0,04$ & 0,147 \\
Sineresis (\%) & & $0,5 \pm 0,00$ & 0,271 \\
\hline
\end{tabular}

disebabkan karena ekstrak etanol daun kembang bulan memiliki $\mathrm{pH}$ yang relatif asam, sehingga penambahan ekstrak etanol daun kembang bulan pada basis gel formula optimum dapat menyebabkan $\mathrm{pH}$ basis gel tersebut semakin turun, menurunnya $\mathrm{pH}$ menyebabkan terbentuknya gel menjadi kurang sempurna sehingga viskositas gel menjadi turun, turunnya viskositas gel berimbas pada semakin besarnya daya sebar gel, gel dengan viskositas yang tinggi cenderung memberikan stabilitas yang baik sehingga karena turunnya viskositas nilai sineresis menjadi meningkat.

\section{Uji Stabilitas Fisik Gel}

Hasil uji stabilitas dipercepat dengan metode freeze thaw cycling menunjukkan bahwa basis gel formula optimum stabil karena tidak adanya nilai pergeseran viskositas, daya sebar, $\mathrm{pH}$, dan sineresis yang signifikan sebelum dan sesudah cycling test,dan gel ekstrak etanol daun kembang bulan memberikan hasil yang tidak stabil karena adanya pergeseran nilai viskositas, daya sebar, $\mathrm{pH}$, dan sineresis yang signifikan sebelum dan sesudah cycling test. Analisis yang digunakan adalah uji t berpasangan.

\section{KESIMPULAN}

Formula optimum gel ekstrak etanol daun kembang bulan terdiri dari 0,81\% carbomer, 5,9\% propilen glikol, dan 0,58\% trietanolamin. Gel ekstrak etanol daun kembang bulan menghasilkan gel yang memenuhi kriteria kecuali viskositas yang terlalu rendah yang menyebabkan gel tidak mampu mempertahankan stabilitas fisiknya. 


\section{DAFTAR PUSTAKA}

Aeni, L. N., Sulaiman, T. S., \& Mulyani, S. (2012). Formulasi Gel Mukoadhesif Kombinasi Minyak Cengkeh dan Getah Jarak Pagar Serta Uji Aktivitas Antibakteri Terhadap Streptococcus Mutant. Majalah Farmaseutik, 8(1), 108-112.

Andisi, R. D., Suling, P. L., \& Kapantow, M. G. (2016). Profil Keloid di Poliklinik Kulit dan Kelamin RSUP prof.Dr. R. D. Kandou Manado Periode Januari 2011-Desember 2015. Jurnal e-Clinic, 4(2).

Bolton, S. \& Bon, C., (2010). Pharmaceutical Statistic and Clinical Application (6 ed.). New York: Marcel Dekker Inc.

Guci, Y., 2015. Indonesia Productivity And Quality Institute. [Online] Tersedia di: https://ipqi.org/kalibrasi-ph-meter/ [Diakses 611 2018].

Kaur, L. P., \& Guleri, T. K. (2013). Topical Gel: A Recent Approach for Novel Drug delivery. Asian Journal of Biomedical \& Pharmaceutical Sciences, 3(17), 1-5.

Kuncari, E. S., Iskandarsyah, \& Praptiwi. (2014). Evaluasi, Uji Stabilitas Fisik dan Sineresis Sediaan Gel yang Mengandung Minoksidil, Apigenin dan Perasan Herba Seledri (Apium graveolens L.), Bul. Penelit. Kasehat, 42(4), 213-222.

Melani, D., Purwanti, T., \& Soeratri, W. (2005). Korelasi Kadar Propilenglikol Dalam Basis Dan Pelepasan Dietilammonium Diklofenak Dari Basis Gel Carbopol ETD 2020. Majalah Farmasi Airlangga, 5(1).

Ogawa, R. (2017, March 10). Keloid and Hypertrophic Scars Are the Result of Chronic Inflammation in the Reticular Dermis. International Journal of Molecular Sciences, 18(606). doi:doi:10.3390/ijms18030606

Patil, S., D.D., G., \& P.B., R. (2015). Design, Development, and Evaluation of Herbal Gel for Treatment of Psoriasis. Journal of Innovation in Pharmaceuticals and Biological Sciences, 2(1), 72-87.

Qisti, B. W., Nurahmanto, D., \& Rosyidi, V. A. (2018). Optimasi Propilen Glikol dan Etanol sebagai Peningkat Penetrasi Ibuprofen dalam Sediaan Gel dengan Metode Simplex Lattice Design. e-Jurnal Pustaka Kesehatan, 6(1).

Rahman, A. G., Astuti, I. Y., \& Dhiani, B. A. (2013). Formulasi Ekstrak Rimpang Bangle
(Zingiber purpurenum roxb) Dengan Variasi Konsentrasi Triethanolamin Sebagai Emulgator Dan Uji Iritasinya. Pharmacy, 10(1), 41-54.

Rowe, R. C., Sheskey, P. J., \& Quinn, M. E. (2009). Handbook of Pharmaceutical Excipients (VI ed.). London: Pharmaceutical Press.

Sari, R., \& Isadiartuti, D. (2006). Studi Aktivitas Sediaan Gel Antiseptik Tangan Ekstrak Daun Sirih (Piper Betle Linn.). Majalah Farmasi Indonesia, 17(4), 163-169.

Sasmita, F. W., Susetyarini, E., Husamah, \& Pantiwati, Y. (2017, Januari). Efek Ekstrak Daun Kembang Bulan (Tithonia diversifolia) terhadap Kadar Glukosa Darah Tikus Wistar (Rattus norvegicus) yang Diinduksi Alloxan. Biosfera, 34(1), 22-31. doi:10.20884/1.mib.2017.34.1.412

Sayuti, N. A. (2015). Formulasi dan Uji Stabilitas Fisik Sediaan Gel Ekstrak Daun Ketapang Cina (Cassia alata L.). Jurnal Kefarmasian Indonesia, 5(2), 74-82.

Septiawan, D. (2012). Perbandingan Jumlah Variasi Triethanolamin Terhadap Stabilitas Fisik dan SIfat Kimia Gel Antiseptik Ekstrak Bunga Rosella (Hibiscus Sabdariffa L.) (Skripsi ed.). Surakarta: Fakultas Matematika dan Ilmu Pengetahuan Alam Universitas Sebelas Maret.

Wahyuningsih, M. S., Wirohadidjodjo, Y. W., Hidayat, R., \& Sadid, A. (2015). Antifibrotic Effect of Standarized Ethanol Extract of Tithonia Diversifolia (Hemsley) A. Grey on Keloid Fibroblast. International Journal of Pharmacognosy and Phytochemical Research, 7(4), 642647.

Ziemons, Goffin, E. \&., Lejeune, E. \&., Cunha, R. \&., Angenot, A. \&., Thunus, L. \&., \& Leopold. (2005). Supercritical carbon dioxide extraction of tagitinin $\mathrm{C}$ from Tithonia diversifolia. Journal of Supercritical Fluids The, 33, 53-59. doi:10.1016/j.supflu.2004.04.001

Zulkarnain, A. K., Marchaban, Wahyuono, S., \& Susidarti, R. A. (2015). Pengaruh Konsentrasi Mahkota Dewa Terhadap Stabilitas Lotion-Krim Serta Uji Tabir Surya Secara Spektrofotometri . Majalah Farmaseutik, 11(3), 328-335. 